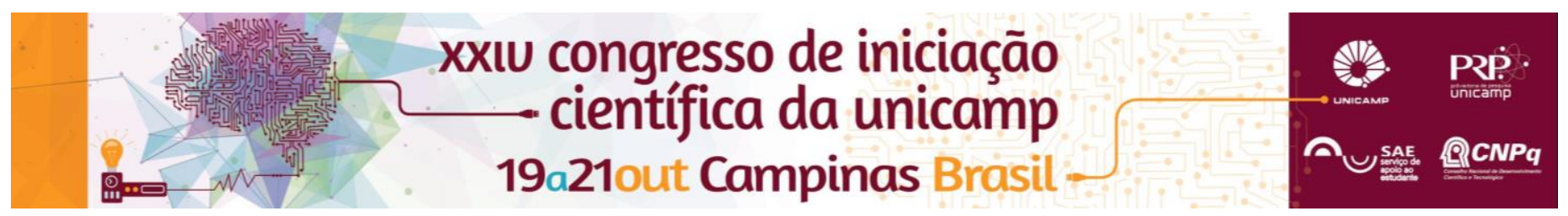

\title{
Região do Parque Via Norte, Campinas: análise do bairro a partir da oferta de serviços ambientais.
}

\author{
Maren L. Sonoda (IC), Prof. Dr. Evandro Ziggiatti Monteiro (Orientador)
}

\begin{abstract}
Resumo
Este projeto de iniciação científica visou compreender as relações e dinâmicas do território de dois bairros na região do Parque Via Norte, em Campinas-SP, através do estudo da oferta de serviços ambientais urbanos. Essa análise constitiu em um levantamento físico-espacial da paisagem desses bairros de forma correlata com os cenários apresentados no relatório "Avaliação Ecossistêmica do Milênio" AEM/ONU (2005). Sendo assim, evidências visíveis dos quatro cenários descritos pelo relatório, na paisagem desses bairros. $E$, de certa forma, compreender sua influência no bem estar de seus cidadãos.
\end{abstract}

\section{Palavras-chave:}

Cenários do Milênio, Paisagem Urbana, Serviços Ambientais.

\section{Introdução}

O objetivo do estudo foi o de entender a qualidade da paisagem urbana, a partir da interação entre o espaço e seus habitantes. Para a análise, utilizaram-se dois conceitos complementares: identificação dos serviços ambientais (BOLUND e HUNHAMMAR, 1999:3) e como esses influenciam o ecossistema; e a percepção da paisagem a partir de trajetos e sucessões de imagens.

Ambos os conceitos foram analisados a partir de duas visões referenciais: o olhar técnico-científico e o do usuário.

Com isso, o diagnóstico final foi feito a partir da identificação de características relacionadas aos Cenários do Milênio (AEM, 2005), e, portanto, estabelecer as possíveis consequências futuras, positivas e negativas, da relação entre o território e os seus habitantes.

\section{Resultados e Discussão}

A partir de uma análise das características presentes nas paisagens e em seus serviços, a área em estudo pode ser setorizada em três zonas: área de uso residencial e industrial; área predominantemente residencial; e área predominantemente industrial e particular.

Nestas zonas, foram identificados os serviços ambientais presentes, tendo em vista a qualidade de vida de seus habitantes.

Visando um melhor estudo, a partir dos conceitos de análise sequencial de Maria Elaine Kohlsdorf (1996), foram determinados três percursos cujas atividades existentes refletissem suas características mais marcantes. Para a análise, os percursos foram realizados a partir de três visões diferentes: o olhar da pesquisadora; de moradores; e de um visitante. Gerando a produção de fotos, descrições e mapas mentais.

Por fim, a partir das análises dos serviços ambientais e da imagem da cidade, foi possível identificar dois cenários predominantes na área de estudo: Ordem pela Força e Mosaico Adaptativo.

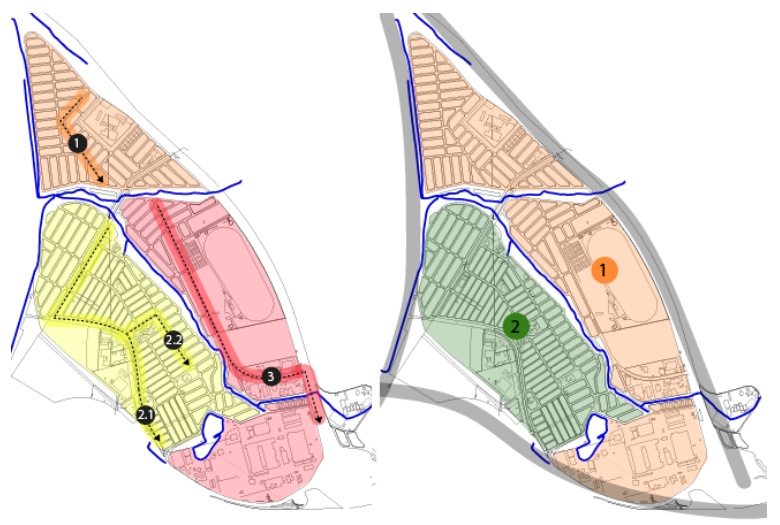

Figura 1. Percursos realizados na área de estudo. Figura 2. Cenários predominantes.

\section{Conclusões}

O bairro reproduz as características históricas, culturais e econômicas da cidade. A paisagem urbana da área em estudo apresenta particularidades que permitiram a identificação dos dois cenários.

A Ordem pela força reflete a necessidade de pequenas ações de integração e convivência, além de uma melhor distribuição das áreas de serviço. Enquanto o Mosaico adaptativo necessita de maiores incentivos, pare que prospere e se expanda. Estes são dois cenários opostos, que evidenciam ao mesmo tempo um conflito e uma oportunidade.

\section{Agradecimentos}

Agradeço aos meus pais e amigos pelo suporte. Agradeço aos membros do Laboratório FLUXUS, pelos materiais concedidos e discussões.

Agradeço ao meu orientador Prof. Dr. Evandro Ziggiatti Monteiro, pela paciência e estímulo.

Agradeço ao Conselho Nacional de Desenvolvimento Cientifico e Tecnológico (CNPQ), pela oportunidade e pela bolsa. 